\title{
Tolerance Mechanisms of the Aromatic and Medicinal Plant Salvia sclarea L. to Excess Zinc
}

\author{
Anelia Dobrikova ${ }^{1, *(1)}$, Emilia Apostolova ${ }^{1}$, Anetta Hanć ${ }^{2} \mathbb{D}$, Ekaterina Yotsova ${ }^{1}$, Preslava Borisova ${ }^{1}$, \\ Ilektra Sperdouli ${ }^{3}$ (D) Ioannis-Dimosthenis S. Adamakis ${ }^{4}$ and Michael Moustakas ${ }^{5}$ (D)
}

1 Institute of Biophysics and Biomedical Engineering, Bulgarian Academy of Sciences, 1113 Sofia, Bulgaria; emya@bio21.bas.bg (E.A.); ekaterina_yotsova@abv.bg (E.Y.); preslavab12345@gmail.com (P.B.)

2 Department of Trace Analysis, Faculty of Chemistry, Adam Mickiewicz University, 61-614 Poznan, Poland; anettak@amu.edu.pl

3 Institute of Plant Breeding and Genetic Resources, Hellenic Agricultural Organisation-Demeter, Thermi, 57001 Thessaloniki, Greece; ilektras@bio.auth.gr

4 Department of Botany, Faculty of Biology, National and Kapodistrian University of Athens, 15784 Athens, Greece; iadamaki@biol.uoa.gr

5 Department of Botany, Aristotle University of Thessaloniki, 54124 Thessaloniki, Greece; moustak@bio.auth.gr

* Correspondence: aneli@bio21.bas.bg

Citation: Dobrikova, A.; Apostolova, E.; Hanć, A.; Yotsova, E.; Borisova, P.; Sperdouli, I.; Adamakis, I.S.; Moustakas, M. Tolerance Mechanisms of the Aromatic and Medicinal Plant Salvia sclarea L. to Excess Zinc. Plants 2021, 10, 194. https://doi.org/ 10.3390/plants10020194

Received: 1 December 2020

Accepted: 18 January 2021

Published: 21 January 2021

Publisher's Note: MDPI stays neutral with regard to jurisdictional claims in published maps and institutional affiliations.

Copyright: (c) 2021 by the authors. Licensee MDPI, Basel, Switzerland. This article is an open access article distributed under the terms and conditions of the Creative Commons Attribution (CC BY) license (https:// creativecommons.org/licenses/by/ $4.0 /)$.

\begin{abstract}
In recent years, due to the development of industrial and agricultural production, heavy metal contamination has attracted increasing attention. Aromatic and medicinal plant Salvia sclarea $\mathrm{L}$. (clary sage) is classified to zinc ( $\mathrm{Zn}$ ) accumulators and considered as a potential plant for the phytoremediation of heavy metal polluted soils. In this study, an adaptation of clary sage to $900 \mu \mathrm{M}$ (excess) $\mathrm{Zn}$ exposure for eight days in a hydroponic culture was investigated. The tolerance mechanisms under excess $\mathrm{Zn}$ exposure were assessed by evaluating changes in the nutrient uptake, leaf pigment and phenolic content, photosynthetic activity and leaf structural characteristics. The uptake and the distribution of $\mathrm{Zn}$, as well as some essential elements such as: $\mathrm{Ca}, \mathrm{Mg}, \mathrm{Fe}, \mathrm{Mn}$ and $\mathrm{Cu}$, were examined by inductively coupled plasma mass spectrometry. The results revealed that Salvia sclarea is a $\mathrm{Zn}$-accumulator plant that tolerates significantly high toxic levels of $\mathrm{Zn}$ in the leaves by increasing the leaf contents of $\mathrm{Fe}, \mathrm{Ca}$ and $\mathrm{Mn}$ ions to protect the photosynthetic function and to stimulate the photosystem I (PSI) and photosystem II (PSII) activities. The exposure of clary sage to excess Zn significantly increased the synthesis of total phenolics and anthocyanins in the leaves; these play an important role in $\mathrm{Zn}$ detoxification and protection against oxidative stress. The lipid peroxidation and electrolyte leakage in leaves, used as clear indicators for heavy metal damage, were slightly increased. All these data highlight that Salvia sclarea is an economically interesting plant for the phytoextraction and/or phytostabilization of Zn-contaminated soils.
\end{abstract}

Keywords: chlorophyll fluorescence; clary sage; nutrient uptake; oxidative stress; photosynthesis; phytoremediation; phytostabilization; pigments; total phenolic content; $\mathrm{Zn}$ toxicity

\section{Introduction}

Heavy metals appear in the environment at high concentrations due to several industrial and agricultural activities and, subsequently, became toxic to all living organisms, including plants. Toxic metals lead to reduced plant growth, altered physiology and metabolism, as well as hamper the plant cell integrity, causing the generation of reactive oxygen species (ROS) [1,2]. Heavy metals also interfere with the uptake of essential nutrients and water, and as a result, crop yields decrease in heavy metal polluted soils [3]. In recent years, increased interest has been focused on some economically important plant species with a high capacity to accumulate heavy metals and an increased tolerance to their toxicity for the purposes of the phytoremediation of contaminated soils [2,4-7]. Plant metal accumulation varies within and between species, development stages, soil and metal types, 
time duration, etc. [3,4,8-11]. Baker et al. [4] proposed that hyperaccumulator species typically maintain high metal concentrations in their tissues without significant toxic symptoms using different mechanisms for detoxification and the sequestration of heavy metals in nontoxic forms [1,2,11-15].

Zinc as a micronutrient is one of the essential elements necessary for optimal growth, development and productivity, since $\mathrm{Zn}$ is a cofactor of many enzymes involved in the biosynthesis of plant growth hormones, respiration and photosynthesis [16-18]. However, $\mathrm{Zn}$ ions in high concentrations induce phytotoxicity, easily affecting the function of many enzymes and proteins, slowing plant metabolism and causing oxidative damage [18-21]. Visible Zn toxicity symptoms include reduced growth, leaf chlorosis (due to decreased chlorophyll content), necrosis, closure of stomata and disturbance of the water balance [22-25]. Photosynthesis is considered the primary physiological process affected by heavy metals directly or indirectly by ROS production damaging the photosynthetic apparatus of plants $[23,26]$. Heavy metals, including $\mathrm{Zn}$, in higher concentrations also induce lipid peroxidation of the photosynthetic membranes, degrade photosynthetic pigments, inhibit photosystem II (PSII) activity and electron transport and decrease both the carboxylation efficiency of Rubisco and net photosynthesis [21,26-28]. The Zn toxicity first affects the chlorophyll content and then inhibits the photochemical activity of PSII [21]. In addition, the effects of Zn toxicity on the photosynthetic apparatus differ with the applied concentrations, the time of exposure, the plant species, etc. $[11,23]$. Chlorophyll fluorescence has been widely used as a quick and a sensitive indicator of heavy metal stress in plants [15,28-35].

In recent years, there has been a growing interest in aromatic plants (some herbs) that are considered suitable for environmentally safe phytoremediation, as these plants are mainly used for secondary products, and their leaf essential oils are free of heavy metals [6,36-38]. The aromatic and medicinal plant clary sage (Salvia sclarea L.) is native to many Mediterranean countries and is an important plant cultivated as a source of essential oils for applications in human medicine or perfumery products [38-40]. This plant is also proposed to be a $\mathrm{Zn}$ and cadmium $(\mathrm{Cd})$ accumulator and a lead $(\mathrm{Pb})$ hyperaccumulator with a good potential for phytoremediation [38,41,42]. Previously, it has been shown that heavy metals from industrial contaminated soils have almost no effect on the development of clary sage, and this plant shows no signs of heavy metal toxicity [38]. Zn effects on the nutrient uptake and functioning of the photosynthetic apparatus, as well as the tolerance mechanisms of S. sclarea to high $\mathrm{Zn}$ concentrations, have not yet been studied. Therefore, the aim of this study was to explore some of the mechanisms involved in $\mathrm{Zn}$ tolerance of clary sage, focusing on the investigation of changes in the uptake and distribution of essential nutrient elements (such as: $\mathrm{Ca}, \mathrm{Mg}, \mathrm{Mn}, \mathrm{Fe}$ and $\mathrm{Cu}$ ), as well as on some defense mechanisms that play an important role in the detoxification of high Zn levels, especially in leaves of $S$. sclarea, exposed to $900 \mu \mathrm{M} Z \mathrm{Zn}$ for eight days in a hydroponic solution. The $\mathrm{Zn}$ tolerance was assessed by measuring oxidative stress markers, changes in leaf photosynthetic pigments, the polyphenolic and anthocyanin contents and leaf structure, as well as by studying the functional activity of the photosynthetic apparatus (PSII and photosystem I (PSI) activities in vivo) using a chlorophyll fluorescence analysis and P700 photooxidation.

The knowledge of these response mechanisms will be useful for the assessment of some tolerance strategies against $\mathrm{Zn}$ stress in this herbal plant and to optimize the management practices for phytoremediation.

\section{Results}

\subsection{Zinc Accumulation and Mineral Element Uptake}

The exposure of Salvia sclarea for eight days to $900 \mu \mathrm{M} Z \mathrm{Zn}$ resulted in a strongly increased $\mathrm{Zn}$ accumulation in both the roots and leaves. The $\mathrm{Zn}$ content in the roots $\left(40,060 \pm 1200 \mu \mathrm{g} \mathrm{g}^{-1}\right.$ dry weight (DW), Figure 1a) was much higher than that in the leaves $\left(1759 \pm 53 \mathrm{\mu g} \mathrm{g}^{-1} \mathrm{DW}\right.$, Figure 2a). The increased Zn uptake was accompanied with a 
significantly increased (about 4.4 times) accumulation of Fe and $\mathrm{Cu}$ in the roots (Figure 1b), as well as an increased accumulation of Fe (by 38\%), Mn (by $85 \%$ ) and Ca (by $22 \%$ ) in the leaves compared to the control plants (Figure 2). Despite the significantly increased $\mathrm{Cu}$ accumulation in the roots, its translocation to the leaves decreased (Figure 3), as the leaf contents of $\mathrm{Cu}$ were similar to the control (Figure $2 \mathrm{~b}$ ). Under excess $\mathrm{Zn}$ exposure, the $\mathrm{Mg}$ contents in the roots decreased by $44 \%$ (Figure 1a) and in the leaves by $10 \%$ (Figure 2a), which were related with an increased translocation factor from the roots to the aboveground parts (Figure 3). In addition to the Mg ions, an increased translocation was also detected for the $\mathrm{Ca}$ and $\mathrm{Mn}$ ions (Figure 3). The translocation factor, showing a plant's ability to translocate metal ions from its roots through the stems to the leaves [43], was less than one for the $\mathrm{Zn}, \mathrm{Fe}$ and $\mathrm{Cu}$ ions and decreased under excess $\mathrm{Zn}$ (Figure 3).

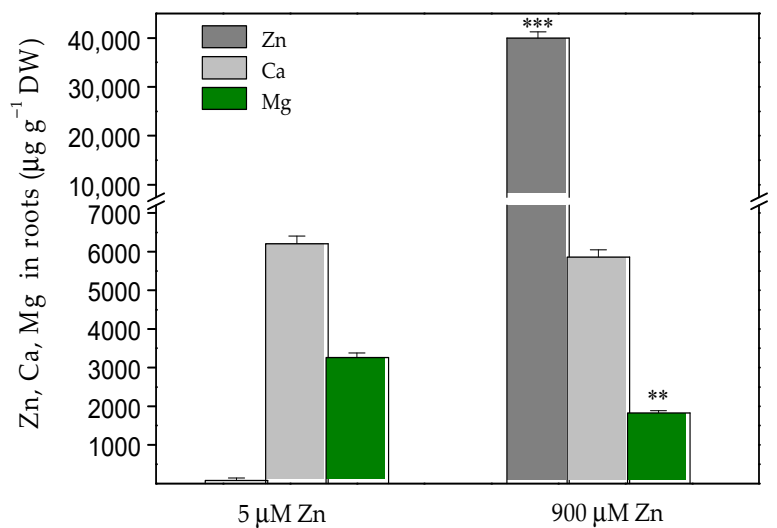

(a)

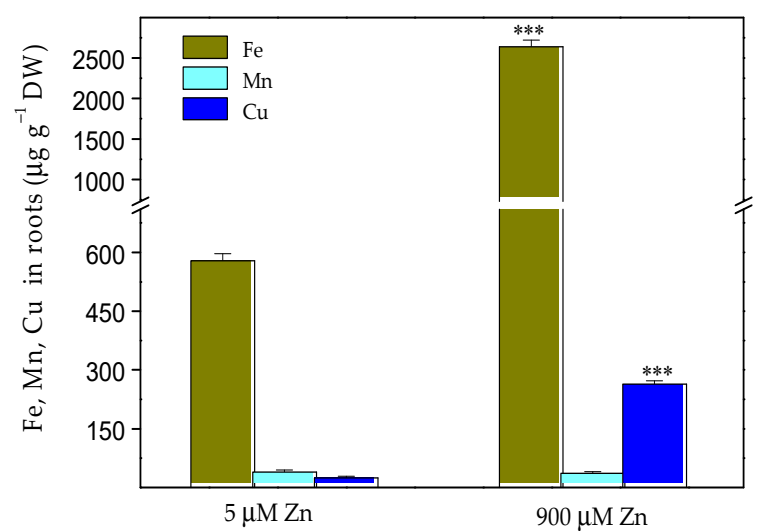

(b)

Figure 1. Contents of $\mathrm{Zn}, \mathrm{Ca}$ and $\mathrm{Mg}(\mathbf{a})$ and $\mathrm{Fe}, \mathrm{Mn}$ and $\mathrm{Cu}(\mathbf{b})$ in Salvia sclarea roots ( $\mu \mathrm{g} \mathrm{g}^{-1}$ dry weight (DW)) after 8 days of exposure at $5 \mu \mathrm{M}$ (control) or $900 \mu \mathrm{M}$ (excess) Zn. Mean values ( $\pm \mathrm{SE}$ ) were compared between the two Zn exposures for the same mineral element using a Student's $t$-test, and the differences were considered statistically significant with ${ }^{* *} p<0.01$ or ${ }^{* * *} p<0.001$.

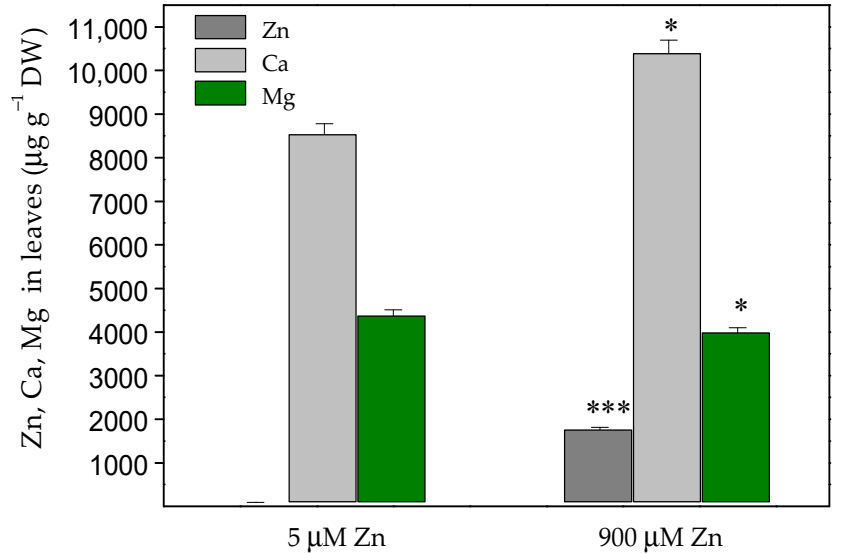

(a)

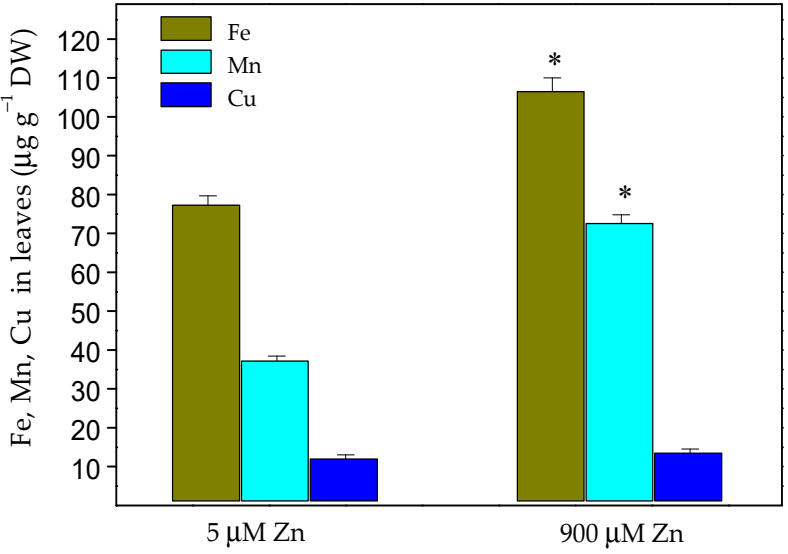

(b)

Figure 2. Contents of $\mathrm{Zn}, \mathrm{Ca}$ and $\mathrm{Mg}(\mathbf{a})$ and $\mathrm{Fe}, \mathrm{Mn}$ and $\mathrm{Cu}(\mathbf{b})$ in Salvia sclarea leaves $\left(\mu \mathrm{g} \mathrm{g}{ }^{-1} \mathrm{DW}\right)$ after 8 days of exposure at $5 \mu \mathrm{M}$ (control) or $900 \mu \mathrm{M}$ (excess) Zn. Mean values ( $\pm \mathrm{SE}$ ) were compared between the two Zn exposures for the same mineral elements using a Student's $t$-test, and the differences were considered statistically significant with * $p<0.05$ or $* * * p<0.001$. 


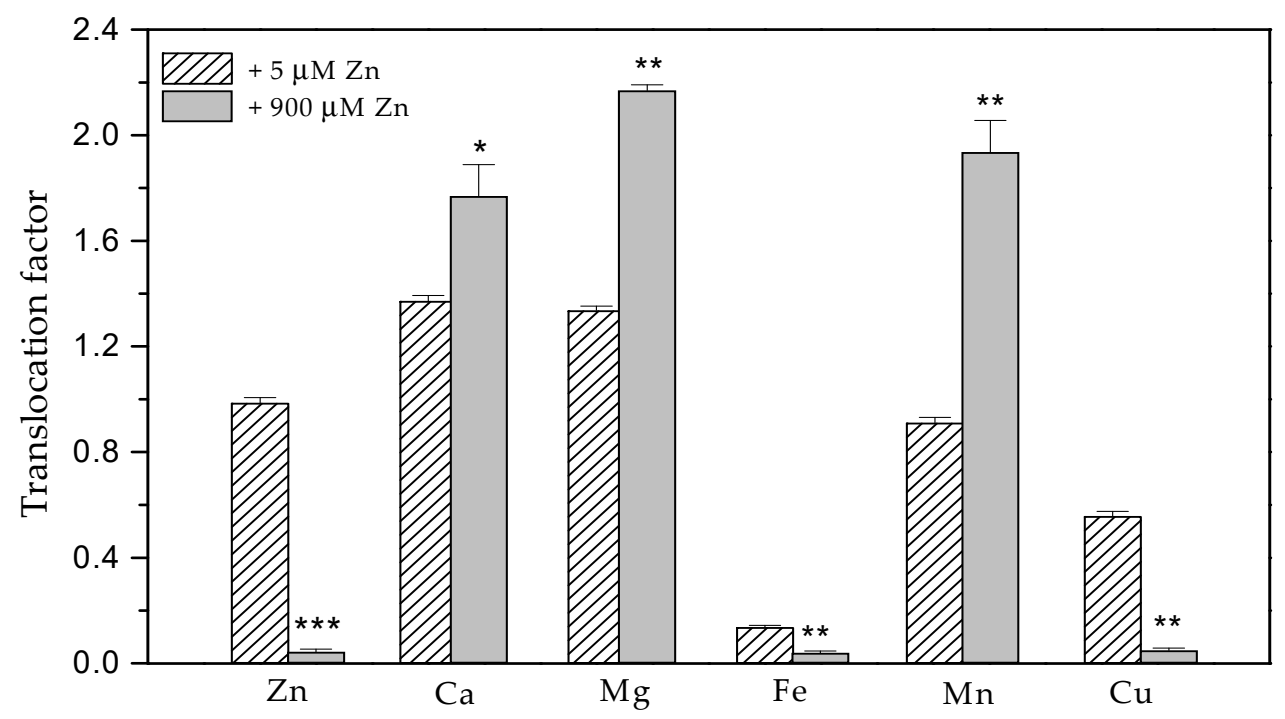

Figure 3. Changes in the translocation factors of the elements in Salvia sclarea plants in response to $5 \mu \mathrm{M}$ (control) or $900 \mu \mathrm{M}$ (excess) Zn exposure for 8 days. Mean values $( \pm \mathrm{SE}$ ) were compared between the two Zn exposures for the same elements using a Student's $t$-test, and the differences were considered statistically significant with ${ }^{*} p<0.05,{ }^{* *} p<0.01$ and $* * * p<0.001$.

\subsection{Oxidative Stress Markers}

Following the changes in relative water contents (RWC) and electrolyte leakages (EL) of the leaves of $S$. sclarea subjected to high $\mathrm{Zn}$ exposure, the impact of $\mathrm{Zn}$ on the leaf cell membrane integrity was evaluated. The results revealed that the $\mathrm{Zn}$ treatment had a slightly negative effect on the leaf membrane permeability of clary sage plants and led to increased EL values (by 22\%) compared to the control leaves (Table 1) without exhibiting any other signs of toxicity (i.e., chlorosis, necrosis, rolling of leaves or disturbances in plant water-balance; Supplemental Figure S1). Additionally, oxidative stress and lipid peroxidation in clary sage leaves caused by high-level Zn exposure were estimated by the hydrogen peroxide $\left(\mathrm{H}_{2} \mathrm{O}_{2}\right)$ and by malondialdehyde (MDA) contents as an indicator of the membrane peroxidation levels. These oxidative stress markers increased $(p<0.05)$ by about $28 \%$ for $\mathrm{H}_{2} \mathrm{O}_{2}$ and $21 \%$ for MDA (Table 1 ).

Table 1. Effects of $5 \mu \mathrm{M}$ (control) or $900 \mu \mathrm{M}$ (excess) Zn exposure for 8 days on the relative water content (RWC), electrolyte leakage (EL) and the contents of hydrogen peroxide $\left(\mathrm{H}_{2} \mathrm{O}_{2}\right)$ and malondialdehyde (MDA) in the leaves of Salvia sclarea.

\begin{tabular}{|c|c|c|c|c|}
\hline & $\begin{array}{c}\text { RWC } \\
(\%)\end{array}$ & $\begin{array}{l}\text { EL } \\
(\%)\end{array}$ & $\begin{array}{c}\mathrm{H}_{2} \mathrm{O}_{2} \\
\left(\mu \mathrm{mol} \mathrm{g}{ }^{-1} \mathrm{FW}\right)\end{array}$ & $\begin{array}{c}\text { MDA } \\
(\mu \mathrm{mol} \mathrm{g}-1 \text { FW })\end{array}$ \\
\hline $5 \mu \mathrm{M} Z \mathrm{Zn}$ & $93 \pm 2^{a}$ & $9.9 \pm 0.4^{b}$ & $34.3 \pm 1.3^{b}$ & $25.9 \pm 1.7^{b}$ \\
\hline $900 \mu \mathrm{M} Z \mathrm{Zn}$ & $89 \pm 2^{a}$ & $12.1 \pm 0.9^{a}$ & $43.8 \pm 2.2^{\mathrm{a}}$ & $31.5 \pm 1.2^{\mathrm{a}}$ \\
\hline
\end{tabular}

Different letters indicate significant differences between the means $( \pm$ SE) for the same parameters $(p<0.05)$. FW-fresh weight.

The histochemical detection of $\mathrm{H}_{2} \mathrm{O}_{2}$ overproduction in the leaves of $\mathrm{Zn}$-stressed S. sclarea plants indicated that the high $\mathrm{Zn}$ exposure caused an accumulation of $\mathrm{H}_{2} \mathrm{O}_{2}$ mainly at the base of the leaf and around the midrib (Figure 4) without ongoing oxidative stress throughout the whole leaf. 


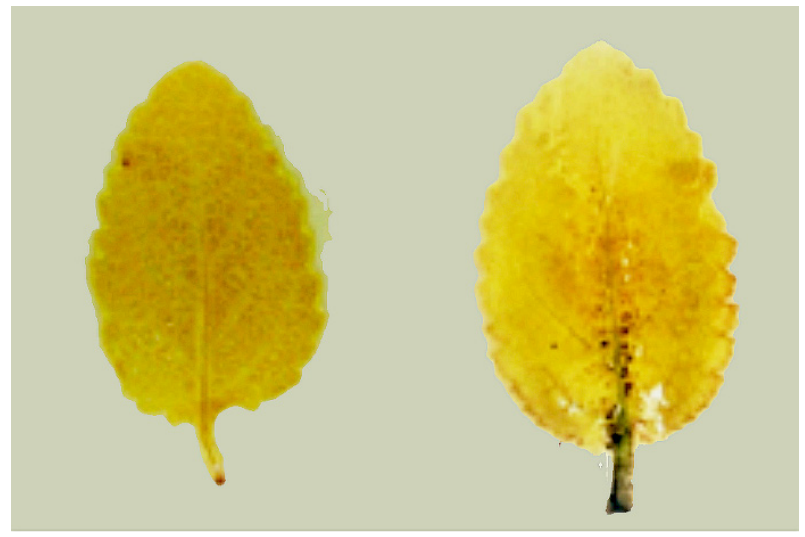

(a)

(b)

Figure 4. Histochemically detected hydrogen peroxide $\left(\mathrm{H}_{2} \mathrm{O}_{2}\right)$ in the leaves of Salvia sclarea forming brown precipitates with $3,3^{\prime}$-diaminobenzidine (DAB) under (a) $5 \mu \mathrm{M}$ (control) or (b) $900 \mu \mathrm{M}$ (excess) Zn levels.

\subsection{Leaf Pigments and Total Phenolic Content}

Measurements of the leaf pigments were used as sensitive biochemical markers for the metal stress and phytotoxicity. After the Zn treatment of S. sclarea plants for eight days, the contents of chlorophyll $a(\mathrm{Chl} a)$ slightly decreased by about $8 \%$, while the contents of $\mathrm{Chl}$ $b$ and the total carotenoids (Cars) did not change compared to those of the control leaves (Figure 5). The results also revealed that, compared to the control clary sage plants, the leaf contents of the total phenolics and anthocyanins increased under excess Zn exposure by $44 \%$ and $40 \%$, respectively.

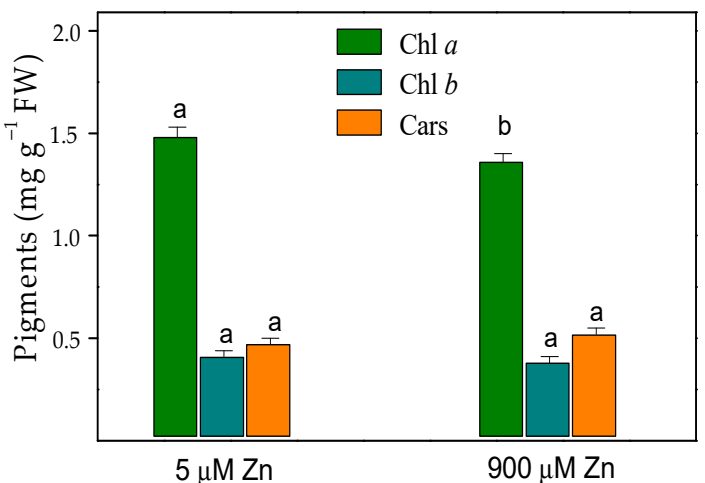

(a)

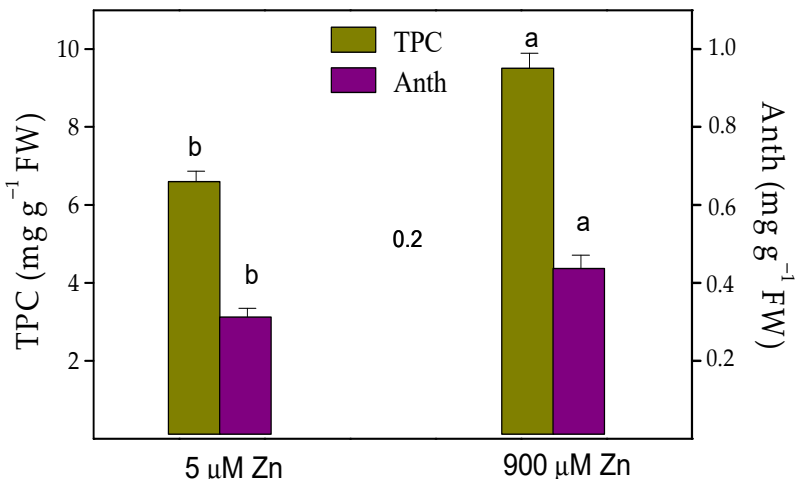

(b)

Figure 5. Effects of $5 \mu \mathrm{M}$ (control) or $900 \mu \mathrm{M}$ (excess) Zn exposure for 8 days on (a) the contents of the pigments: chlorophylls $(\mathrm{Chl} a$ and $\mathrm{Chl} b$ ) and carotenoids (Cars) and (b) total phenolic contents (TPC; expressed as mg of a gallic acid equivalent per g FW) and anthocyanins (Anth; expressed as mg of a cyanidin-3-glucoside equivalent per g FW) in the leaves of Salvia sclarea. Different letters indicate significant differences between the mean values $( \pm \mathrm{SE})$ for the same parameters $(p<0.05)$.

\subsection{Chlorophyll Fluorescence Analysis}

Here, we estimated the maximum efficiency of the PSII photochemistry (Fv/Fm), as well as the quantum efficiency of PSII photochemistry ( $\left.\Phi_{\mathrm{PSII}}\right)$, the quantum yield of regulated energy dissipation in PSII $\left(\Phi_{\mathrm{NPQ}}\right)$, the quantum yield of nonregulated energy dissipation in PSII ( $\left.\Phi_{N O}\right)$ and the fraction of open reaction centers ( $\left.\mathrm{q} p\right)$. After eight days of excessive $\mathrm{Zn}$ exposure $(900 \mu \mathrm{M})$, the Fv/Fm did not differ compared to the control (5 $\mu \mathrm{M}$ $Z n$ ), while the $\Phi_{\text {PSII }}$ increased by about $13 \%(p<0.01$ ) (Figure 6a). Due to this increased $\Phi_{\mathrm{PSII}}$, a statistically significant decrease in $\Phi_{\mathrm{NO}}$ and $\Phi_{\mathrm{NPQ}}$ compared to the controls was detected (Figure $6 \mathrm{~b})$. These three quantum yields ( $\Phi_{\mathrm{PSII}}, \Phi_{\mathrm{NPQ}}$ and $\left.\Phi_{\mathrm{NO}}\right)$ are equal to one, 
assuming that the absorbed light energy is either utilized or dissipated. The increase of $\Phi_{\text {PSII }}$ compared to the control after the eight days of $\mathrm{Zn}$ exposure was due to a significant $(p<0.01)$ increase in the fraction of open PSII reaction centers ( $q p)$ compared to the control. Under $900 \mu \mathrm{M} Z \mathrm{Zn}$ exposure, a total of $89 \%$ reaction centers were open, while under control conditions (5 $\mu \mathrm{M} \mathrm{Zn})$, only $79 \%$ were open.

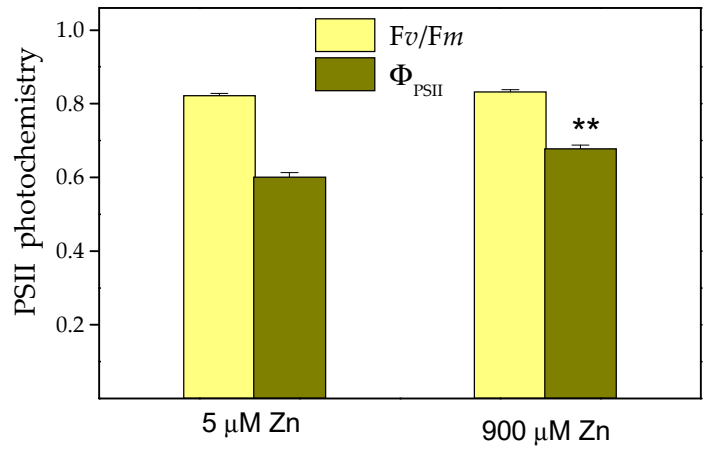

(a)

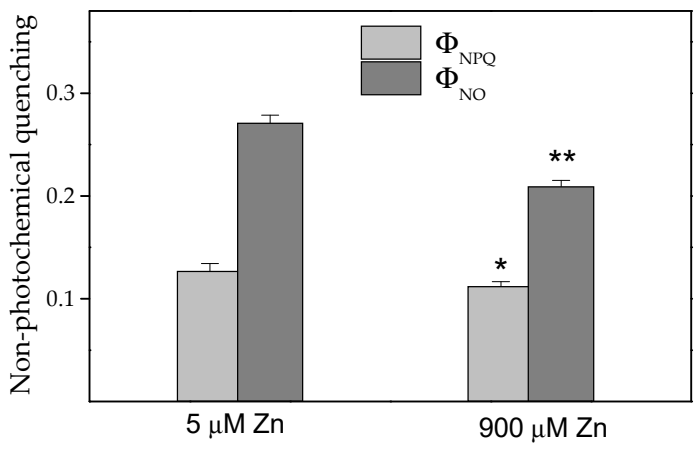

(b)

Figure 6. Changes in the maximum efficiency of the photosystem II (PSII) photochemistry (Fv/Fm) and the quantum efficiency of the PSII photochemistry $\left(\Phi_{\mathrm{PSII}}\right)(\mathbf{a})$, as well as in the quantum yield of regulated energy dissipation in PSII $\left(\Phi_{\mathrm{NPQ}}\right)$ and in the quantum yield of nonregulated energy dissipation in PSII ( $\left.\Phi_{\mathrm{NO}}\right)(\mathbf{b})$, of Salvia sclarea leaves after exposure to $5 \mu \mathrm{M}$ (control) or $900 \mu \mathrm{M}$ (excess) Zn for 8 days. Mean values ( $\pm \mathrm{SE}$ ) were compared between the two treatments for the same parameter using a Student's $t$-test, and the differences were considered statistically significant with ${ }^{*} p<0.05$ or ** $p<0.01$.

\subsection{P700 Photooxidation}

The measurements of the steady-state P700 photooxidation $\left(\mathrm{P} 700^{+}\right)$by far-red (FR) light-induced absorbance changes at $830 \mathrm{~nm}\left(\Delta A_{830}\right)$ were conducted to access changes in the PSI photochemistry of $S$. sclarea leaves after high levels of $\mathrm{Zn}$ exposure for eight days. The $\mathrm{P} \mathrm{OO}^{+}$reduction after turning off the FR light was characterized by an exponential decay (within half the time, $t_{1 / 2}$ ), as shown in our previous study [44]. The amount of $\mathrm{P} 700^{+}$(measured as $\left.\Delta A / A_{830}\right)$ was increased by $18 \%(p<0.05)$ after the $900 \mu \mathrm{M} \mathrm{Zn}$ exposure in comparison to the control (Table 2). The subsequent half-time $\left(t_{1 / 2}\right)$ of the $\mathrm{P} \mathrm{PO}^{+}$dark reduction was not statistically different from that in the control plants.

Table 2. Effects of $5 \mu \mathrm{M}$ (control) or $900 \mu \mathrm{M}$ (excess) Zn exposure on the far-red (FR) light-induced P700 photooxidation $\left(\mathrm{P} 700^{+}\right)$and the kinetics of the $\mathrm{P} 700^{+}$dark reduction (half-time, $t_{1 / 2}$ ) in the leaves of Salvia sclarea. $\triangle A / A_{830}$ - the relative amplitudes of the $\mathrm{P} 00^{+}$absorbance changes at $830 \mathrm{~nm}$.

\begin{tabular}{ccc}
\hline & $\mathbf{P 7 0 0}^{+}$ & $\boldsymbol{t}_{\mathbf{1 / 2}}(\mathbf{s})$ \\
\hline $5 \mu \mathrm{M} Z \mathrm{Zn}$ & $11.46 \pm 0.35^{\mathrm{b}}$ & $2.31 \pm 0.22^{\mathrm{a}}$ \\
$900 \mu \mathrm{M} \mathrm{Zn}$ & $13.52 \pm 0.43^{\mathrm{a}}$ & $1.97 \pm 0.18^{\mathrm{a}}$ \\
\hline
\end{tabular}

Different letters indicate significant differences between the mean values $( \pm \mathrm{SE})$ for the same parameters $(p<0.05)$

\subsection{Leaf Anatomy under Zn Stress}

Excess Zn slightly affected the leaf anatomy of S. sclarea (Figure 7), though the leaves' basic structures remained unaltered (compare Figure $7 \mathrm{a}$ with Figure $7 \mathrm{~b}$ ). However, more stomata could be observed in transverse sections (circles in Figure $7 \mathrm{~b}$ ), and the epidermal cells contained darkly stained materials (arrowheads and asterisks in Figure 7b). The stomatal density $\left(\mathrm{No} / \mathrm{mm}^{2}\right.$ ) specifically increased in the leaf upper epidermis (Figure 7c), and the stomata numbers seemed to double upon $900 \mu \mathrm{M}$ (excess) $\mathrm{Zn}$ application. 


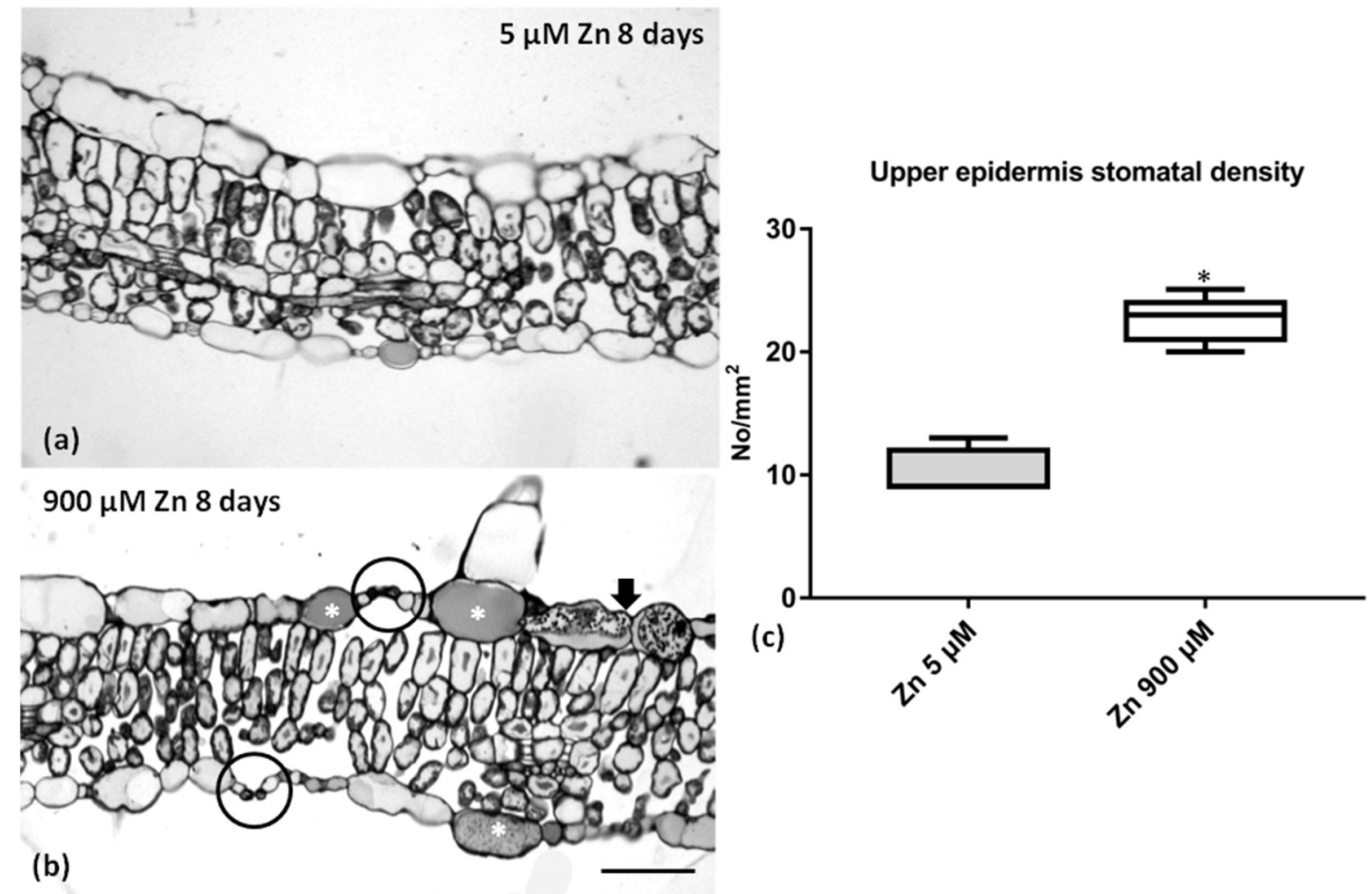

Figure 7. Transverse sections of $S$. sclarea leaves from (a) $5 \mu \mathrm{M}$ (control) or (b) $900 \mu \mathrm{M}$ (excess) Zn 8-day-treated plants. (c) Stomatal density $\left(\mathrm{No} / \mathrm{mm}^{2}\right)$ in the upper epidermis of both control and excess Zn-treated plants. Upon excess $\mathrm{Zn}$ application, some additional stomata could be observed (circles in (b)), while the epidermal cells contained darkly stained materials (asterisks and arrows in (b)). (c) Data are presented as means from sections from 4 individual leaves $\left({ }^{*} p<0.05\right)$. Scale bar: $100 \mu \mathrm{m}$.

\section{Discussion}

Recently, it has been reported that $S$. sclarea grown in heavy metal-polluted areas accumulate heavy metals through the root system and then translocate them to the aboveground parts [38,42]. Our data revealed a higher accumulation of $\mathrm{Zn}$ in the roots than in the aboveground parts (Figures 1a and 2a) and significantly decreased the translocation factor under excess $\mathrm{Zn}$ exposure (Figure 3). A similar decrease in the translocation of heavy metals to the aboveground parts was observed in sage plants (Salvia officinalis) grown in contaminated soils [45]. The decreased $\mathrm{Zn}$ translocation was also reported in some hyperaccumulating plants when grown hydroponically $[17,34,46]$. Moreover, a translocation factor of less than one suggests that plants remediate $\mathrm{Zn}$ by concentrating the metals in the roots $[43,47]$. Therefore, when grown hydroponically, S. sclarea phytostabilizes $\mathrm{Zn}$ in its roots.

The suggested Zn value for hyperaccumulation is $10,000 \mu \mathrm{g} \mathrm{g}^{-1}$ leaf DW $(>1 \% \mathrm{DW})[4,9]$. In our experimental conditions, the $S$. sclarea leaves did not reach these values; therefore, the clary sage can be characterized as a $\mathrm{Zn}$ accumulator, confirming previous observations with these plants grown in contaminated soils [38]. The presence of 8.0-100 $\mu \mathrm{g} \mathrm{Zn} \mathrm{g}{ }^{-1} \mathrm{DW}$ has been suggested to assist in the normal growth and development of plants, but higher contents above $300 \mu \mathrm{g} \mathrm{g}^{-1} \mathrm{DW}(>0.03 \% \mathrm{DW})$ were considered toxic for plants $[18,48]$ and to cause the overproduction of ROS [21]. In this study, after excess $\mathrm{Zn}$ exposure, we detected high $\mathrm{Zn}$ concentrations of about $1759 \mu \mathrm{g} \mathrm{Zn} \mathrm{g}{ }^{-1} \mathrm{DW}(>0.17 \% \mathrm{DW})$ in the leaves (Figure 2a), without any symptoms of toxicity (i.e., chlorosis, necrosis, rolling of the leaves or disturbances in the RWC) (Supplemental Figure S1 and Table 1) or affecting the leaves' structure (Figure 7). Similar high $\mathrm{Zn}$ concentrations were also measured in the leaves of the hyperaccumulator Noccaea caerulescens grown hydroponically with an $800 \mu \mathrm{M}$ Zn supply [34]. 
Moreover, Zn can interfere with the uptake of some other trace elements, leading to an imbalance in the nutrient uptake, transport and use (see $[25,34,49])$. A previous study with hyperaccumulator Noccaea caerulescens under high $\mathrm{Zn}$ exposure showed a reduced uptake of $\mathrm{Mn}, \mathrm{Cu}, \mathrm{Ca}$ and $\mathrm{Mg}$ ions, as well as an enhanced uptake of Fe and $\mathrm{Zn}$, while the $\mathrm{Ca}$ and $\mathrm{Mg}$ concentrations in the aboveground tissues remain unchanged, and the $\mathrm{Cu}$ increased significantly [34].

Our results demonstrated that an increased Zn uptake is accompanied with a significantly increased accumulation of $\mathrm{Fe}$ and $\mathrm{Cu}$ ions in the roots (Figure 1b), as well as increased accumulation of $\mathrm{Fe}, \mathrm{Mn}$ and $\mathrm{Ca}$ ions in the leaves compared to the control plants (Figure 2). On the other hand, despite significantly increased Fe accumulation in roots and leaves (Figures $1 \mathrm{~b}$ and $2 \mathrm{~b}$ ), its translocation factor to the aboveground tissues is decreased (Figure 3).

The observed increase of the nutrient elements in the leaves of $S$. sclarea (for Fe, Ca and $\mathrm{Mn}$ ) or the maintenance of almost the same (slightly diminished for $\mathrm{Mg}$ ) concentrations as in the control plants is most likely included in clary sage's protective strategy against $\mathrm{Zn}$ stress. Moreover, the $\mathrm{Fe}, \mathrm{Ca}$ and $\mathrm{Mg}$ cations have major roles in regulating (directly or indirectly) the photosynthetic efficiency [49]. In contrast to previous reports [50], which found no effect or an antagonistic effect of the Zn status on the Fe uptake, here, we observed a synergistic effect in the Fe uptake that suggested a strategy of an increase in Fe accumulation as a response to a possible risk of Fe deficiency in leaves (reviewed in [25]). Iron is an essential trace element required for respiration and photosynthesis and many fundamental biological redox reactions [25,51]. In the light reactions of photosynthesis, it has been also found that Fe protects the PSII from the photoinhibition that occurs under Fe deficiency [51], as well as the Fe supplement, maintaining photosynthetic electron transport [52]. Therefore, the observed increased Fe accumulation in the leaves upon $900 \mu \mathrm{M} Z \mathrm{n}$ exposure could be one of the reasons for the increased quantum efficiency of the PSII photochemistry ( $\Phi_{\text {PSII }}$ (Figure 6a), as well as the increased photooxidation of PSI (Table 2).

Excess $\mathrm{Zn}$ had a significant effect on the $\mathrm{Mg}$ ion uptake, as the $\mathrm{Mg}$ contents in the roots decreased significantly (Figure 1a); however, its translocation to the aboveground parts strongly increased, leading to slightly diminished $\mathrm{Mg}$ leaf contents by $10 \%$ (Figures 2a and 3). This was also accompanied by a slightly decreased (by $8 \%$ ) amount of $\mathrm{Chl} a$ in leaves, while no noticeable changes were detected in the Chl $b$ and Car contents in the leaves (Figure 5a). Recently, a significant negative correlation was reported between the $\mathrm{Zn}$ concentrations in the leaves and the amount of Chl $a$ in Trapa natans L., confirming the leaf $\mathrm{Chl} a$ content as a sensitive biomarker for stress [53]. All of the above suggests a higher $\mathrm{Zn}$ tolerance for S. sclarea. At the same time, the $\mathrm{Ca}$ and $\mathrm{Mn}$ ion contents in the leaves and their translocation factors in clary sage plants were enhanced under exposure to $900 \mu \mathrm{M}$ (excess) $\mathrm{Zn}$ in comparison to the control levels of $\mathrm{Zn}(5 \mu \mathrm{M})$ (Figures 2 and 3). It has been proposed that $\mathrm{Ca}$ cations are necessary not only for the normal function of the oxygen-evolving complex but, also, for the regulation of Calvin cycle enzymes [54].

It is generally considered that ROS overproduction under heavy metal stress is a key response that can promote the lipid peroxidation of membranes, causing a disruption of their integrity (i.e., the MDA and EL increased). Therefore, the contents of $\mathrm{H}_{2} \mathrm{O}_{2}$ and MDA are frequently used as indicators of oxidative stress. This study provided evidence that an excess $\mathrm{Zn}$ treatment did not induce oxidative stress, since $S$. sclarea leaves displayed attenuated or no symptoms of toxicity, coupled with lower $\mathrm{H}_{2} \mathrm{O}_{2}$ and MDA contents (Table 1), and less accumulation of $\mathrm{H}_{2} \mathrm{O}_{2}$ in the whole leaves (Figure 4). In comparison to the control leaves, after excess $\mathrm{Zn}$ exposure, the $\mathrm{H}_{2} \mathrm{O}_{2}$ contents were higher by $28 \%$, leading to a slightly enhanced (by 21\%) lipid peroxidation (estimated as changes in the MDA contents) and EL values (Table 1), while no disturbances in the water balance (RWC) of the leaves were detected, suggesting a higher tolerance of S. sclarea to Zn exposure. Jin et al. [55] reported that elevated levels of Zn cause a significantly higher accumulation of $\mathrm{H}_{2} \mathrm{O}_{2}$ in the leaves of the non-hyperaccumulating ecotype of Sedum alfredii, leading to a 
strong increase (over five times) in the MDA contents, while, in the hyperaccumulating ecotype, this increase was less pronounced up to $1000 \mu \mathrm{M} \mathrm{Zn}$. A previous study with sage plants grown in heavy metal-polluted soil suggested that the neutralization of $\mathrm{H}_{2} \mathrm{O}_{2}$ is a nonenzymatic rather than an enzymatic process, as indicated by the weak activities of the most antioxidant enzymes [45]. The production of $\mathrm{H}_{2} \mathrm{O}_{2}$ can also act as a longdistance signaling molecule activating antioxidant defense mechanisms in plants under stress $[56,57]$.

It has been suggested that increased leaf phenolic compounds in some herb plants have an important role in preventing oxidative stress, thus increasing the heavy metal tolerance [58,59]. Therefore, the observed tolerance of clary sage leaves accumulating high $\mathrm{Zn}$ concentrations may be due to the significantly increased amounts of total phenolics and anthocyanins (Figure 5). In the leaf epidermis, the content of dark materials (Figure 7) may indicate an increase in the phenolic content. Chen et al. [60] reported a reduced Chl $a$ content accompanied by a significantly increased total phenolic content in the leaves of Kandelia obovata under high Zn concentrations, indicating that heavy metal tolerance is related to the metabolism of phenolic compounds. Furthermore, Vidal et al. [61] confirmed that plants that produce high amounts of phenolic compounds as a response to heavy metal stress could be good candidates for phytoremediation and/or phytostabilization. Additionally, anthocyanins have also been reported to have remarkably high antioxidant capacity, acting as ROS scavengers in vacuoles and, thus, counteracting the toxic effects of heavy metals $[1,62,63]$. Therefore, their enhanced accumulation in clary sage leaves upon excess Zn exposure (Figure 5) indicates that a mechanism of heavy metal tolerance [64], such as the formation of anthocyanin-chelate-metal complexes in plant tissues, is also possible [65].

Generally, Zn excess was found to strongly affect the leaf structure. In particular, Zn-treated poplar leaves increased in thickness with their pasalidae parenchyma to substantially increase in volume [66], while in Zn-treated Hordeum vulgare leaves, a decrease in cell size and intercellular spaces with an increase in metal concentrations were recorded [67]. The Zn-treated S. sclarea plants showed none of the above effects. Both the control and excess $Z$ n-treated leaves of $S$. sclarea had a single-layered epidermis on the upper and lower surfaces of the leaves (Figure 7). The bifacial leaves had a two to three layers of palisade parenchyma, and the spongy parenchyma consisted of irregularly shaped cells (Figure 7) having the typical anatomical features reported by Özdemir and Şenel [68]. One other interesting feature was the increase in stomatal density (Figure 7c), a phenomenon that occurred also in peanut plants under excess Zn application [69]. The increased stomata number may enhance the carbon uptake, while, at the same time, minimize the water loss [70], and this could explain the non-RWC disturbance observed (Table 1).

Since the photosynthetic efficiency is a sensitive bioindicator of environmental stress [33], our data demonstrated stimulated PSII and PSI activity after excess Zn exposure (Figure 6a and Table 2), while there were no changes in the dark-adapted $\mathrm{F}_{v} / \mathrm{F}_{m}$ ratio (Figure $6 \mathrm{a}$ ) or in the $\mathrm{O}_{2}$ evolution (data not shown).

The analysis of the photooxidation of $\mathrm{P} 700$ to $\mathrm{P} 700^{+}$, reflecting the relative contents of active PSI reaction centers, was used to assess the effects of high $\mathrm{Zn}$ accumulation in leaves on the PSI activity in vivo. The level of $\mathrm{P} 00^{+}$is suggested to be a direct and sensitive indicator of the electron acceptance capacity from the PSI [71]. The current results revealed that the functioning of the PSI in S. sclarea leaves was stimulated under excess Zn exposure (Table 2). In contrast to the observed tolerance of S. sclarea to high Zn exposure, our recent study [72] revealed that $100 \mu \mathrm{M} \mathrm{Cd}$ exposure for eight days caused higher toxic effects in $S$. sclarea plants, expressed by a stronger reduction in the chlorophyll contents, as well as by an inhibition of oxygen evolution and the activities of both photosystems. 


\section{Materials and Methods}

\subsection{Plant Growth Conditions and Zn Treatment}

Seeds of clary sage (Salvia sclarea L., Lamiaceae) were kindly provided by Bio Cultures Ltd. (Karlovo, Bulgaria). After initial germination, seeds were sown into pots filled with soil mixed with perlite $(2: 1 v / v)$ for about 6 weeks and then were transferred for 2 weeks into hydroponic containers ( 3 to 4 seedlings per container) filled with a continuously aerated nutrient solution ( $\mathrm{pH}$ 6.0) described previously in detail [35]. The seedlings were kept in greenhouse under $220 \mu \mathrm{mol} \mathrm{m}^{-2} \mathrm{~s}^{-1}$ photon flux density and a 12-h light photoperiod at $25 / 20^{\circ} \mathrm{C}$. Uniform plants were selected and subjected to treatment with $5 \mu \mathrm{M}$ (control) or $900 \mu \mathrm{M}$ (excess) $\mathrm{Zn}$ (applied as $\mathrm{ZnSO}_{4}$ and considered on the basis of earlier research [34]) in the nutrient solution for 8 days. For each treatment, 3 containers with four plants were prepared, and the nutrient solutions were renewed every three days. Measurements were performed on the fully expanded upper leaves of the plants.

\subsection{Analyses of Zn and Nutrient Element Accumulation by the Inductively Coupled Plasma Mass} Spectrometry Method

After 8 days of treatment with $5 \mu \mathrm{M}$ (control) or $900 \mu \mathrm{M}$ (excess) Zn, roots and leaves from treated plants were harvested, washed in deionized water and dried at $75{ }^{\circ} \mathrm{C}$ to constant biomass, then milled (ball mill Pulverisette 23, Fritsch, Germany) and, finally, sieved through a polypropylene sieve. The dried tissue samples $(\sim 0.3 \mathrm{~g})$ were digested in closed quartz vessels in a 3:1 ratio of 65\% nitric acid and 30\% hydrogen peroxide (Suprapur, Merck, Germany). The temperature of digestion was $200{ }^{\circ} \mathrm{C}$ using a microwave-assisted digestion system Ethos One (Milestone S.r.l., Sorisole BG, Italy). Digested samples were quantitatively transferred into polypropylene tubes and diluted with demineralized water (Direct-Q 3UV, Merc, Darmstadt, Germany). Elemental analysis of $\mathrm{Zn}, \mathrm{Ca}, \mathrm{Cu}, \mathrm{Fe}, \mathrm{Mg}$ and Mn was carried out on an ICP-MS model Elan DRC II (PerkinElmer Sciex, Toronto, ON, Canada). Spectral interference was eliminated using the dynamic reaction cell (DRC) mode with high-purity ammonia (Linde Gas, Poznan, Poland) as the reaction gas. The non-spectral interferences were reduced using a $10 \mathrm{ug} \mathrm{L}^{-1}$ solution of $\mathrm{Ge}$ and $\mathrm{Rh}$ as the internal standard. The series of standard solutions for calibration were prepared by appropriate dilution of $10 \mathrm{mg} \mathrm{L}^{-1}$ multielement stock solution (Multi-Element Calibration Standard 3, PerkinElmer Pure, Shelton, CT, USA). Calibration curves were determined by the interpolation method. The analytical procedure was validated using the certified reference material: trace elements in spinach leaves NIST SRM 1570a (National Institute of Standards and Technology, Standard Reference Material, Gaithersburg, MD, USA). More detail information about the ICP-MS operation conditions, settings and quality assurance are given in Appendix A.

\subsection{Determination of the Oxidative Stress Markers}

For the determination of electrolyte leakage (EL), some fully expanded leaves from different selected plants were cut into small pieces and placed in $40 \mathrm{~mL}$ tubes with distilled water for $24 \mathrm{~h}$ at $25^{\circ} \mathrm{C}$ in the dark. After that, the electrical conductivity of the solutions (EC1) was measured with a conductometer (Hydromat LM302, Witten, Germany); then, the samples were boiled for $30 \mathrm{~min}$ and cooled to $25^{\circ} \mathrm{C}$, and their final electrical conductivity was measured again (EC2). The electrolyte leakage (EL) was estimated from the equation: $\mathrm{EL}(\%)=(\mathrm{EC} 1 / \mathrm{EC} 2) \times 100$. The relative water content $(\mathrm{RWC})$ of the leaves was calculated as described previously [73].

Fresh leaf samples $(0.1 \mathrm{~g})$ were immediately frozen in liquid nitrogen and stored at $-80{ }^{\circ} \mathrm{C}$ for the analysis of the hydrogen peroxide $\left(\mathrm{H}_{2} \mathrm{O}_{2}\right)$ and malondialdehyde (MDA) contents. The determination of the $\mathrm{H}_{2} \mathrm{O}_{2}$ contents in the leaves and levels of lipid peroxidation by estimating the MDA contents were made as described by Mostofa et al. [74]. The histochemical detection of $\mathrm{H}_{2} \mathrm{O}_{2}$ in leaves by staining with $1 \%$ 3, $3^{\prime}$-diaminobenzidine (DAB) solution were made following the procedure described in [75]. The mean values $( \pm \mathrm{SE})$ were averaged from three independent treatments with 3 repetitions for each treatment. 


\subsection{Analysis of Photosynthetic Pigments and Total Phenolic Content}

Finely ground frozen leaf material $(0.05 \mathrm{~g})$ was extracted with an ice-cold $80 \%(v / v)$ acetone. The homogenates were centrifuged at $5000 \times \mathrm{g}$ for $10 \mathrm{~min}$ at $0-4{ }^{\circ} \mathrm{C}$, and the supernatant was measured spectrophotometrically (Specord 210 Plus, Ed. 2010, Analytik Jena AG, Germany). The amounts of chlorophyll $a(\mathrm{Chl} a)$, chlorophyll $b(\mathrm{Chl} b)$ and carotenoids (Cars) were calculated according to Lichtenthaler [76].

For an estimation of the anthocyanin and total phenolic contents, the frozen leaf samples $(0.1 \mathrm{~g})$ were extracted with $10 \mathrm{~mL}$ acidified methanol $(1 \% \mathrm{HCl})$ in darkness at $0-4{ }^{\circ} \mathrm{C}$ for 2 days. The extracts were clarified by filtration and then used for analyses. Total phenolic content was determined by the Folin-Ciocalteu's colorimetric method, as described by Sripakdee et al. [77]. The optical density was measured spectrophotometrically at $765 \mathrm{~nm}$, and the phenolic content was expressed as $\mathrm{mg}$ of gallic acid equivalent (GAE) per $\mathrm{g}$ fresh weight (FW) of leaf tissues. Anthocyanins were estimated spectrophotometrically as the optical density of the supernatant measured at 535 and $657 \mathrm{~nm}$ was calculated as described by Mancinelli et al. [78]. Anthocyanin content was expressed as $\mathrm{mg}$ of cyanidin-3-glucoside equivalent per $g$ FW. The mean values $( \pm S E)$ were averaged from three independent treatments with 3 repetitions for each treatment.

\subsection{Chlorophyll Fluorescence Analysis}

Chlorophyll fluorescence analysis was performed using an Imaging PAM M-Series system (Heinz Walz GmbH, Effeltrich, Germany), as described in detail [79]. Measurements were conducted in dark-adapted ( $20 \mathrm{~min}$ ) Salvia sclarea plants grown with $5 \mu \mathrm{M}$ (control) or $900 \mu \mathrm{M}$ (excess) Zn for 8 days. The chlorophyll fluorescence parameters that were calculated by the Imaging Win V2.41a software (Heinz Walz GmbH, Effeltrich, Germany) involved the maximum efficiency of PSII photochemistry (Fv/Fm), the effective quantum yield $\left(\Phi_{P S I I}\right)$, the fraction of open reaction centers $(\mathrm{q} p)$, the quantum yield of regulated nonphotochemical energy loss $\left(\Phi_{N P Q}\right)$ and the quantum yield of nonregulated energy $\left(\Phi_{N O}\right)$. The light intensity of $220 \mu \mathrm{mol}$ photons $\mathrm{m}^{-2} \mathrm{~s}^{-1}$ was used for the photosynthetic efficiency measurements, similar to the growth light intensity.

\subsection{Measurements of P700 Photooxidation}

The P700 photooxidation, i.e., the oxidation of the PSI reaction centers (P700) to $\mathrm{P} 700^{+}[80]$, was measured in vivo by the far-red (FR) light-induced absorbance transients at $830 \mathrm{~nm}\left(\Delta A_{830}\right)$ using a PAM-101/103 fluorometer (Walz, Effeltrich, Germany) equipped with an ED-800T emitter-detector. The measurements were performed on dark-adapted leaves using FR light supplied by a photodiode (102-FR, Walz). The extent of the FRinduced oxidation of $\mathrm{P} 700$ to $\mathrm{P} 700^{+}$was estimated as the relative ratio $\Delta A / A_{830}$, where $\Delta A_{830}$ was the FR-induced absorbance change $\left(\mathrm{P} 700^{+}\right)$and $A$ was the absorbance in darkness. The capacity of the cyclic electron flow was estimated by the half-time of the $\mathrm{P} \mathrm{O0}^{+}$dark reduction $\left(t_{1 / 2}\right)$ signal after switching off the FR light, as shown previously [44].

\subsection{Light Microscopy and Stomatal Density Mesuarments}

Pieces of S. sclarea leaves from plants exposed to $5 \mu \mathrm{M}$ (control) or $900 \mu \mathrm{M}$ (excess) $\mathrm{Zn}$ for 8 days were prepared for chemical fixation, as reported in [81]. Pieces were fixed firstly in a $3 \%$ paraformaldehyde $+3 \%$ glutaraldehyde solution buffered with $0.05 \mathrm{M}$ sodium cacodylate at $\mathrm{pH} 7.0$ at room temperature for $6 \mathrm{~h}$, and subsequently, the leaf segments were post-fixed in $2 \%$ osmium tetroxide similarly buffered for $3 \mathrm{~h}$. Afterwards, they were dehydrated in an acetone series, treated with propylene oxide and, finally, embedded in Durcupan ACM resin. An ultramicrotome (LKB 8801A, Stockholm, Sweden) equipped with a glass knife was used to obtained semi-thin sections $(0.5-2 \mu \mathrm{m})$ that were stained with $0.5 \%(w / v)$ toluidine blue $\mathrm{O}$ and observed with a Zeiss Axioplan light microscope equipped with a digital AxioCam MRc 5 camera (Zeiss, Berlin, Germany). The stomatal density $\left(\mathrm{No} / \mathrm{mm}^{2}\right)$ was also evaluated in the leaf upper epidermis paradermal semithin 
sections [82] in both $5 \mu \mathrm{M}$ and $900 \mu \mathrm{M}$ Zn-exposed plants. Paradermal sections were obtained from 4 individual leaves from the central part of the leaf blade.

\subsection{Statistical Analysis}

Average data are presented as the mean values $( \pm \mathrm{SE})$ of three independent experiments with three repetitions each. Statistical analysis of means was performed using two-sample Student's $t$-tests. Differences were considered statistically significant at ${ }^{*} p<0.05,{ }^{* *} p<0.01$ and ${ }^{* * *} p<0.001$ by using Origin 9.0 software (OriginLab, Northampton, MA, USA).

\section{Conclusions}

To the best of our knowledge, this study revealed for the first time some of the tolerance mechanisms of the aromatic and medicinal plant S. sclarea to high $\mathrm{Zn}$ levels in the leaves, which included: (1) an altered uptake and distribution of some essential nutrients, resulting in increased contents of $\mathrm{Fe}, \mathrm{Ca}$ and $\mathrm{Mn}$ ions in the leaves and (2) an enhanced leaf content of nonenzymatic antioxidants, such as total phenolics and anthocyanins. Our results also suggested that these mechanisms are involved into $\mathrm{Zn}$ detoxification and protection against oxidative damage, thus protecting the photosynthetic activity and even stimulating the PSI and PSII activities. Therefore, $S$. sclarea can be used for the environmentally safe phytoremediation/phytoextraction of Zn-contaminated soils, since this aromatic plant is mainly used for secondary products (free of heavy metals); thus, the contamination of the food chain is eliminated.

Future investigations should be focused on the details of the metabolic pathways and enzymatic antioxidant mechanisms that also contribute to the enhanced $\mathrm{Zn}$ tolerance in Salvia sclarea L.

Supplementary Materials: The following are available online at https:/ /www.mdpi.com/2223-774 7/10/2/194/s1: Figure S1: Salvia sclarea L. plants exposed to $5 \mu \mathrm{M} Z n$ (control) or $900 \mu \mathrm{M}$ (excess) $\mathrm{Zn}$ for 8 days in a hydroponic solution.

Author Contributions: Conceptualization, A.D. and M.M.; methodology, A.H., I.-D.S.A., I.S., A.D. and M.M.; software, A.D. and I.-D.S.A.; validation, A.D. and M.M.; formal analysis, A.H., A.D., I.-D.S.A., I.S. and M.M.; investigation, A.H., I.-D.S.A., I.S., A.D., E.Y. and P.B.; resources, I.-D.S.A., A.H., A.D., E.A. and M.M.; writing—original draft preparation, A.D.; writing—review and editing, I.-D.S.A., A.H., E.A. and M.M. and supervision and project administration, A.D. and M.M. All authors have read and agreed to the published version of the manuscript.

Funding: This work was supported by the Agreement for scientific cooperation between the Bulgarian Academy of Sciences and the Aristotle University of Thessaloniki, Greece. A.H. was supported by a grant of the National Science Center in Poland, № 2017/01/X/ST4/00373.

Institutional Review Board Statement: Not applicable.

Informed Consent Statement: Not applicable.

Data Availability Statement: Not applicable

Acknowledgments: The Salvia sclarea seeds used for the experiments were kindly provided by Bio Cultures Ltd.

Conflicts of Interest: The authors declare no conflict of interest.

\section{Appendix A}

\section{Appendix A.1. ICP-MS Operation Condition and Setting}

The study was carried out using an ICP-MS spectrometer equipped with a cyclonic spray chamber, concentric nebulizer of Meinhard type, quadrupole analyzer and $\mathrm{Pt}$ cones. ICP-MS operation conditions were optimized daily. Those condition were: $1250 \mathrm{~W} R \mathrm{RF}$ power, $16 \mathrm{~L} \mathrm{~min}^{-1}$ plasma gas flow rate, $0.89-0.91-\mathrm{L} \mathrm{min}^{-1}$ nebulizer gas flow rate and 
1.2 $\mathrm{L} \mathrm{min}^{-1}$ auxiliary gas flow rate. The daily performance of ICP-MS was evaluated by the Smart Tune Solution, Elan DRC/Plus/II (PerkinElmer, Shelton, CT, USA).

\section{Appendix A.2. Quality Assurance}

In order to provide high-quality results, the analytical procedure was validated. The parameters evaluated for the validation process included linearity, limit of detection (LOD), precision and trueness. Calibration curves were constructed daily and were based on the blank solution with an analyte addition covering a concentration range: $0-1500 \mu \mathrm{g} \mathrm{L}^{-1}$ for ${ }^{24} \mathrm{Mg},{ }^{44} \mathrm{Ca}$ and ${ }^{57} \mathrm{Fe}$ and $0-100 \mu \mathrm{g} \mathrm{L}{ }^{-1}$ for ${ }^{66} \mathrm{Zn},{ }^{55} \mathrm{Mn}$ and ${ }^{63} \mathrm{Cu}$. The correlation coefficient $\mathrm{R}$ exceeded a value of 0.999 for all elements. The trueness of the analytical results was evaluated through the analysis of the certified reference materials and was expressed as a recovery in percentages $(\mathrm{R}, \%)$. The percentages of recoveries for all elements varied from $95 \%$ to $106 \%$, respectively. The Student's $t$-test confirmed a good agreement of trueness with the certified values for all the determined elements. The precision values, expressed as the coefficient of variation in percentages $(\mathrm{CV}, \%)$ for all elements, were from $1.6 \%$ to $3.7 \%$. The limit of detection (LOD) was estimated based on the standard deviation of the 10 separate blank solutions $\left(2 \% \mathrm{HNO}_{3}\right)$ and the slope of the curve (b), according to the equation: $\mathrm{LOD}=3.3 \mathrm{~S} / \mathrm{b}$. The LODs estimated for the ICP-MS method were as follows: $0.01 \mu \mathrm{g} \mathrm{g}^{-1}(\mathrm{Zn}), 30 \mu \mathrm{g} \mathrm{g}^{-1}(\mathrm{Ca}), 0.05 \mu \mathrm{g} \mathrm{g}{ }^{-1}(\mathrm{Cu}), 40 \mu \mathrm{g} \mathrm{g}^{-1}(\mathrm{Fe}), 0.8 \mu \mathrm{g} \mathrm{g}^{-1}(\mathrm{Mg})$ and $0.03 \mu \mathrm{g} \mathrm{g}^{-1}(\mathrm{Mn})[72]$.

\section{References}

1. Sytar, O.; Kumar, A.; Latowski, D.; Kuczynska, P.; Strzałka, K.; Prasad, M. Heavy metal-induced oxidative damage, defense reactions, and detoxification mechanisms in plants. Acta Physiol. Plant. 2013, 35, 985-999. [CrossRef]

2. Saleem, M.H.; Ali, S.; Rehman, M.; Hasanuzzaman, M.; Rizwan, M.; Irshad, S.; Shafiq, F.; Iqbal, M.; Alharbi, B.M.; Alnusaire, T.S.; et al. Jute: A potential candidate for phytoremediation of metals. A Review. Plants 2020, 9, 258. [CrossRef]

3. Clemens, S.; Ma, J.F. Toxic heavy metal and metalloid accumulation in crop plants and foods. Ann. Rev. Plant Biol. 2016, 67, 489-512. [CrossRef]

4. Baker, A.J.M.; McGrath, S.P.; Reeves, R.D.; Smith, J.A.C. Metal hyperaccumulator plants: A review of the ecology and physiology of a biological resource for phytoremediation of metal-polluted soils. In Phytoremediation of Contaminated Soil and Water; Terry, N., Banuelos, G., Eds.; Lewis Publ. CRC: Boca Raton, FL, USA, 2000; pp. 85-107.

5. Małecka, A.; Konkolewska, A.; Hanć, A.; Barałkiewicz, D.; Ciszewska, L.; Ratajczak, E.; Staszak, A.M.; Kmita, H.; Jarmuszkiewicz, W. Insight into the phytoremediation capability of Brassica juncea (v. Malopolska): Metal accumulation and antioxidant enzyme activity. Int. J. Mol. Sci. 2019, 20, 4355-4372.

6. Pandey, J.; Verma, R.K.; Singh, S. Suitability of aromatic plants for phytoremediation of heavy metal contaminated areas: A review. Int. J. Phytoremediation 2019, 21, 405-418. [CrossRef] [PubMed]

7. Rehman, M.Z.; Rizwan, M.; Sohail, M.I.; Ali, S.; Waris, A.A.; Khalid, H.; Naeem, A.; Ahmad, H.R.; Rauf, A. Opportunities and challenges in the remediation of metal-contaminated soils by using tobacco (Nicotiana tabacum L.): A critical review. Environ. Sci. Pollut. Res. 2019, 26, 18053-18070. [CrossRef] [PubMed]

8. Rascio, N.; Navari-Izzo, F. Heavy metal hyperaccumulating plants: How and why do they do it? And what makes them so interesting? Plant Sci. 2011, 180, 169-181. [CrossRef]

9. Dar, M.I.; Khan, F.A.; Rehman, F.; Masoodi, A.; Ansari, A.A.; Varshney, D.; Naushin, F.; Naikoo, M.I. Roles of Brassicaceae in phytoremediation of metals and metalloids. In Phytoremediation; Ansari, A., Gill, S., Gill, R., Lanza, G., Newman, L., Eds.; Springer: Cham, Switzerland, 2015; pp. 201-215. [CrossRef]

10. Rehman, M.Z.; Rizwan, M.; Ali, S.; Ok, Y.S.; Ishaque, W.; Nawaz, M.F.; Akmal, F.; Waqar, M. Remediation of heavy metal contaminated soils by using Solanum nigrum: A review. Ecotoxicol. Environ. Saf. 2017, 143, 236-248. [CrossRef]

11. Dinh, N.; van der Ent, A.; Mulligan, D.R.; Nguyen, A.V. Zinc and lead accumulation characteristics and in vivo distribution of $\mathrm{Zn}^{2+}$ in the hyperaccumulator Noccaea caerulescens elucidated with fluorescent probes and laser confocal microscopy. Environ. Exp. Bot. 2018, 147, 1-12. [CrossRef]

12. Reeves, R.D.; Baker, A.J.M. Metal-accumulating plants. In Phytoremediation of Toxic Metals: Using Plants to Clean Up the Environment; Raskin, I., Ensley, B., Eds.; Wiley: New York, NY, USA, 2000; pp. 193-229.

13. Hall, J.L. Cellular mechanisms for heavy metal detoxification and tolerance. J. Exp. Bot. 2002, 53, 1-11. [CrossRef]

14. Mesnoua, M.; Mateos-Naranjo, E.; Barcia-Piedras, J.M.; Pérez-Romero, J.A.; Lotmani, B.; Redondo-Gómez, S. Physiological and biochemical mechanisms preventing Cd-toxicity in the hyperaccumulator Atriplex halimus L. Plant Physiol. Biochem. 2016, 106, 30-38. [CrossRef] [PubMed]

15. Bayçu, G.; Gevrek-Kürüm, N.; Moustaka, J.; Csatári, I.; Rognes, S.E.; Moustakas, M. Cadmium-zinc accumulation and photosystem II responses of Noccaea caerulescens to Cd and Zn exposure. Environ. Sci. Pollut. Res. 2017, 24, 2840-2850. [CrossRef] [PubMed] 
16. Cakmak, I. Possible roles of zinc in protecting plant cells from damage by reactive oxygen species. New Phytol. 2000, 146, 185-205. [CrossRef]

17. Broadley, M.R.; White, P.J.; Hammond, J.P.; Zelko, I.; Lux, A. Zinc in plants. New Phytol. 2007, 173, 677-702. [CrossRef]

18. Anjum, N.A.; Singh, H.P.; Khan, M.I.R.; Masood, A.; Per, T.S.; Negi, A.; Ahmad, I. Too much is bad-An appraisal of phytotoxicity of elevated plant-beneficial heavy metal ions. Environ. Sci. Pollut. Res. 2015, 22, 3361-3382. [CrossRef]

19. Anwaar, S.A.; Ali, S.; Ali, S.; Ishaque, W.; Farid, M.; Farooq, M.A.; Najeeb, U.; Abbas, F.; Sharif, M. Silicon (Si) alleviates cotton (Gossypium hirsutum L.) from zinc ( $\mathrm{Zn}$ ) toxicity stress by limiting $\mathrm{Zn}$ uptake and oxidative damage. Environ. Sci. Pollut. Res. 2015, 22, 3441-3450. [CrossRef]

20. Noulas, C.; Tziouvalekas, M.; Karyotis, T. Zinc in soils, water and food crops. J. Trace Elem. Med. Biol. 2018, 49, 252-260. [CrossRef]

21. Khan, M.I.R.; Jahan, B.; Alajmi, M.F.; Rehman, M.T.; Khan, N.A. Exogenously-sourced ethylene modulates defense mechanisms and promotes tolerance to zinc stress in mustard (Brassica juncea L.). Plants 2019, 8, 540. [CrossRef]

22. Sagardoy, R.; Vázquez, S.; Florez-Sarasa, I.D.; Albacete, A.; Ribas-Carbó, M.; Flexas, J.; Abadía, J.; Morales, F. Stomatal and mesophyll conductances to $\mathrm{CO} 2$ are the main limitations to photosynthesis in sugar beet (Beta vulgaris) plants grown with excess zinc. N. Phytol. 2010, 187, 145-158. [CrossRef]

23. Vassilev, A.; Nikolova, A.; Koleva, L.; Lidon, F. Effects of excess Zn on growth and photosynthetic performance of young bean plants. J. Phytol. 2011, 3, 58-62.

24. Morina, F.; Jovanović, L.; Prokić, L.; Veljović-Jovanović, S. Physiological basis of differential zinc and copper tolerance of Verbascum populations from metal-contaminated and uncontaminated areas. Environ. Sci. Pollut. Res. 2016, 23, 10005-10020. [CrossRef] [PubMed]

25. Andresen, E.; Peiter, E.; Küpper, H. Trace metal metabolism in plants. J. Exp Bot. 2018, 69, 909-954. [CrossRef]

26. Szopiński, M.; Sitko, K.; Gieroń, Ż.; Rusinowski, S.; Corso, M.; Hermans, C.; Verbruggen, N.; Małkowski, E. Toxic Effects of Cd and $\mathrm{Zn}$ on the photosynthetic apparatus of the Arabidopsis halleri and Arabidopsis arenosa pseudo-metallophytes. Front. Plant Sci. 2019, 10, 748. [CrossRef] [PubMed]

27. Mishra, S.; Dubey, R. Heavy metal toxicity induced alterations in photosynthetic metabolism in plants. In Handbook of Photosynthesis; Pessarakli, M., Ed.; CRC Press: Boca Raton, FL, USA, 2005; pp. 845-863.

28. Paunov, M.; Koleva, L.; Vassilev, A.; Vangronsveld, J.; Goltsev, V. Effects of different metals on photosynthesis: Cadmium and zinc affect chlorophyll fluorescence in durum wheat. Int. J. Mol. Sci. 2018, 19, 787. [CrossRef]

29. Murchie, E.H.; Lawson, T. Chlorophyll fluorescence analysis: A guide to good practice and understanding some new applications. J. Exp. Bot. 2013, 64, 3983-3998. [CrossRef] [PubMed]

30. Guidi, L.; Calatayud, A. Non-invasive tools to estimate stress-induced changes in photosynthetic performance in plants inhabiting Mediterranean areas. Environ. Exp. Bot. 2014, 103, 42-52. [CrossRef]

31. Kalaji, H.M.; Jajoo, A.; Oukarroum, A.; Brestic, M.; Zivcak, M.; Samborska, I.A.; Cetner, M.D.; Łukasik, I.; Goltsev, V.; Ladle, R.J. Chlorophyll a fluorescence as a tool to monitor physiological status of plants under abiotic stress conditions. Acta Physiol. Plant. 2016, 38, 102. [CrossRef]

32. Bayçu, G.; Moustaka, J.; Gevrek-Kürüm, N.; Moustakas, M. Chlorophyll fluorescence imaging analysis for elucidating the mechanism of photosystem II acclimation to cadmium exposure in the hyperaccumulating plant Noccaea caerulescens. Materials 2018, 11, 2580. [CrossRef]

33. Sitko, K.; Rusinowski, S.; Kalaji, H.M.; Szopiński, M.; Małkowski, E. Photosynthetic efficiency as bioindicator of environmental pressure in A. halleri. Plant Physiol. 2017, 175, 290-302. [CrossRef]

34. Moustakas, M.; Bayçu, G.; Gevrek-Kürüm, N.; Moustaka, J.; Csatári, I.; Rognes, S.E. Spatiotemporal heterogeneity of photosystem II function during acclimation to zinc exposure and mineral nutrition changes in the hyperaccumulator Noccaea caerulescens. Environ. Sci. Pollut. Res. 2019, 26, 6613-6624. [CrossRef]

35. Moustakas, M.; Hanć, A.; Dobrikova, A.; Sperdouli, I.; Adamakis, I.D.S.; Apostolova, E. Spatial heterogeneity of cadmium effects on Salvia sclarea leaves revealed by Chlorophyll fluorescence imaging analysis and laser ablation inductively coupled plasma mass spectrometry. Materials 2019, 12, 2953. [CrossRef] [PubMed]

36. Zu, Y.; Li, Y.; Chen, J.; Chen, H.; Li, Q.; Schvartz, C. Hyperaccumulation of Pb, Zn and Cd in herbaceous grown on lead-zinc mining area in Yunnan, China. Environ. Int. 2005, 31, 755-762.

37. Zheljazkov, V.D.; Craker, L.E.; Xing, B.; Nielsen, N.E.; Wilcox, A. Aromatic plant production on metal contaminated soils. Sci. Total Environ. 2008, 395, 51-62. [CrossRef] [PubMed]

38. Angelova, V.R.; Ivanova, R.V.; Todorov, G.M.; Ivanov, K.I. Potential of Salvia sclarea L. for phytoremediation of soils contaminated with heavy metals. Int. J. Agric. Biosyst. Eng. 2016, 10, 780-790.

39. Peana, A.T.; Moretti, M.D.L. Pharmacological activities and applications of Salvia sclarea and Salvia desoleana essential oils. Stud. Nat. Prod. Chem. 2002, 26, 391-423.

40. Kuźma, L.; Kalemba, D.; Rózalski, M.; Rózalska, B.; Wieckowska-Szakiel, M.; Krajewska, U.; Wysokińska, H. Chemical composition and biological activities of essential oil from Salvia sclarea plants regenerated in vitro. Molecules 2009, 14, 1438-1447. [CrossRef]

41. Zheljazkov, V.D.; Nielsen, N.E. Growing clary sage (Salvia sclarea L.) in heavy metal-polluted areas. Acta Hortic. 1996, 426, 309-328. [CrossRef] 
42. Chand, S.; Yaseen, M.; Rajkumari; Patra, D.D. Application of heavy metal rich tannery sludge on sustainable growth, yield and metal accumulation by clary sage (Salvia sclarea L.). Int. J. Phytoremediat. 2015, 17, 1171-1176. [CrossRef]

43. Nirola, R.; Megharaj, M.; Palanisami, T.; Aryal, R.; Venkateswarlu, K.; Naidu, R. Evaluation of metal uptake factors of native trees colonizing an abandoned copper mine-A quest for phytostabilization. J. Sustain. Min. 2015, 14, 115-123. [CrossRef]

44. Dobrikova, A.G.; Yotsova, E.K.; Börner, A.; Landjeva, S.P.; Apostolova, E.L. The wheat mutant DELLA-encoding gene (Rht-B1c) affects plant photosynthetic responses to cadmium stress. Plant Physiol. Biochem. 2017, 114, 10-18. [CrossRef]

45. Stancheva, I.; Geneva, M.; Hristozkova, M.; Markovska, Y.; Salamon, I. Antioxidant capacity of sage grown on heavy metalpolluted soil. Russ. J. Plant Physiol. 2010, 57, 799-805. [CrossRef]

46. Schvartzman, M.; Corso, M.; Fataftah, N.; Scheepers, M.; Nouet, C.; Bosman, B.; Carnol, M.; Motte, P.; Verbruggen, N.; Hanikenne, M. Adaptation to high zinc depends on distinct mechanisms in metallicolous populations of Arabidopsis halleri. New Phytol. 2018, 218, 269-282. [CrossRef] [PubMed]

47. Usman, K.; Al-Ghouti, M.A.; Abu-Dieyeh, M.H. The assessment of cadmium, chromium, copper, and nickel tolerance and bioaccumulation by shrub plant Tetraena qataranse. Sci. Rep. 2019, 9, 5658. [CrossRef] [PubMed]

48. Marschner, H. Mineral Nutrition of Higher Plants, 2nd ed.; Academic Press: London, UK, 1995.

49. Szabò, I.; Spetea, C. Impact of the ion transportome of chloroplasts on the optimization of photosynthesis. J. Exp. Bot. 2017, 68, 3115-3128. [CrossRef]

50. Lombi, E.; Tearall, K.L.; Howarth, J.R.; Zhao, F.J.; Hawkesford, M.J.; McGrath, S.P. Influence of iron status on cadmium and zinc uptake by different ecotypes of the hyperaccumulator Thlaspi caerulescens. Plant Physiol. 2002, 128, 1359-1367. [CrossRef] [PubMed]

51. Saito, A.; Iino, T.; Sonoike, K.; Miwa, E.; Higuchi, K. Remodeling of the major light-harvesting antenna protein of PSII protects the young leaves of barley (Hordeum vulgare L.) from photoinhibition under prolonged iron deficiency. Plant Cell Physiol. 2010, 51, 2013-2030. [CrossRef]

52. Sebastian, A.; Prasad, M.N.V. Iron- and manganese-assisted cadmium tolerance in Oryza sativa L.: Lowering of rhizotoxicity next to functional photosynthesis. Planta 2015, 241, 1519-1528. [CrossRef]

53. Petrovic, D.; Krivokapic, S. The effect of $\mathrm{Cu}, \mathrm{Zn}, \mathrm{Cd}$, and $\mathrm{Pb}$ accumulation on biochemical parameters (proline, chlorophyll) in the water caltrop (Trapa natans L.), Lake Skadar, Montenegro. Plants 2020, 9, 1287. [CrossRef]

54. Hochmal, A.K.; Schulze, S.; Trompelt, K.; Hippler, M. Calcium dependent regulation of photosynthesis. Biochim. Biophys. Acta 2015, 1847, 993-1003. [CrossRef]

55. Jin, X.F.; Yang, X.E.; Islam, E.; Liu, D.; Mahmood, Q.; Li, H.; Li, J. Ultrastructural changes, zinc hyperaccumulation and its relation with antioxidants in two ecotypes of Sedum alfredii Hance. Plant Physiol. Biochem. 2008, 46, 997-1006. [CrossRef]

56. Jiménez, A.; Martí, M.C.; Camejo, D.; Sevilla, F. Hydrogen peroxide and nitric oxide metabolism in chloroplasts. In Nitric Oxide and Hydrogen Peroxide Signaling in Higher Plants; Gupta, D., Palma, J., Corpas, F., Eds.; Springer: Cham, Switzerland, 2019; pp. 107-144.

57. Adamakis, I.D.S.; Sperdouli, I.; Eleftheriou, E.P.; Moustakas, M. Hydrogen peroxide production by the spot-like mode action of bisphenol A. Front. Plant Sci. 2020, 11, 1196. [CrossRef] [PubMed]

58. Michalak, A. Phenolic compounds and their antioxidant activity in plants growing under heavy metal stress. Pol. J. Environ. Stud. 2006, 15, 523-530.

59. Farouk, S.; Al-Amri, S.M. Exogenous melatonin-mediated modulation of arsenic tolerance with improved accretion of secondary metabolite production, activating antioxidant capacity and improved chloroplast ultrastructure in rosemary herb. Ecotoxicol. Environ. Saf. 2019, 180, 333-347. [CrossRef] [PubMed]

60. Chen, S.; Wang, Q.; Lu, H.; Li, J.; Yang, D.; Liu, J.; Yan, C. Phenolic metabolism and related heavy metal tolerance mechanism in Kandelia Obovata under Cd and Zn stress. Ecotoxicol. Environ. Saf. 2019, 169, 134-143. [CrossRef] [PubMed]

61. Vidal, C.; Ruiz, A.; Ortiz, J.; Larama, G.; Perez, R.; Santander, C.; Ferreira, P.; Cornejo, P. Antioxidant responses of phenolic compounds and immobilization of copper in Imperata Cylindrica, a plant with potential use for bioremediation of $\mathrm{Cu}$ contaminated environments. Plants 2020, 9, 1397. [CrossRef]

62. Moustaka, J.; Panteris, E.; Adamakis, I.D.S.; Tanou, G.; Giannakoula, A.; Eleftheriou, E.P.; Moustakas, M. High anthocyanin accumulation in poinsettia leaves is accompanied by thylakoid membrane unstacking, acting as a photoprotective mechanism, to prevent ROS formation. Environ. Exp. Bot. 2018, 154, 44-55. [CrossRef]

63. Moustaka, J.; Tanou, G.; Giannakoula, A.; Adamakis, I.D.S.; Panteris, E.; Eleftheriou, E.P.; Moustakas, M. Anthocyanin accumulation in poinsettia leaves and its functional role in photo-oxidative stress. Environ. Exp. Bot. 2020, 175, 104065. [CrossRef]

64. Kapoor, D.; Singh, M.P.; Kaur, S.; Bhardwaj, R.; Zheng, B.; Sharma, A. Modulation of the functional components of growth, photosynthesis, and anti-oxidant stress markers in cadmium exposed Brassica juncea L. Plants 2019, 8, 260. [CrossRef]

65. Landi, M.; Tattini, M.; Gould, K.S. Multiple functional roles of anthocyanins in plant-environment interactions. Environ. Exp. Bot. 2015, 119, 4-17. [CrossRef]

66. Todeschini, V.; Lingua, G.; D'Agostino, G.; Carniato, F.; Roccotiello, E.; Berta, G. Effects of high zinc concentration on poplar leaves: A morphological and biochemical study. Environ. Exp. Bot. 2011, 71, 50-56. [CrossRef]

67. Sridhar, B.B.M.; Han, F.X.; Diehl, S.V.; Monts, D.L.; Su, Y. Effects of Zn and Cd accumulation on structural and physiological characteristics of barley plants. Brazil. J. Plant Physiol. 2007, 19, 15-22. [CrossRef]

68. Özdemir, C.; Şenel, G. The morphological, anatomical and karyological properties of Salvia sclarea L. Turk. J. Bot. 1999, 23, 7-18. 
69. Shi, G.R.; Cai, Q.S. Photosynthetic and anatomic responses of peanut leaves to zinc stress. Biol. Plantarum 2009, 53, 391-394. [CrossRef]

70. Bertolino, L.T.; Caine, R.S.; Gray, J.E. Impact of stomatal density and morphology on water-use efficiency in a changing world. Front. Plant Sci. 2019, 10, 225. [CrossRef] [PubMed]

71. Munekage, Y.; Hashimoto, M.; Miyake, C.; Tomizawa, K.; Endo, T.; Tasaka, M.; Shikanai, T. Cyclic electron flow around photosystem I is essential for photosynthesis. Nature 2004, 429, 579-582. [CrossRef] [PubMed]

72. Dobrikova, A.; Apostolova, E.; Hanć, A.; Yotsova, E.; Borisova, P.; Sperdouli, I.; Adamakis, I.D.S.; Moustakas, M. Cadmium toxicity in Salvia sclarea L.: An integrative response of element uptake, oxidative stress markers, leaf structure and photosynthesis. Ecotoxicol. Environ. Saf. 2021, 209, 111851. [CrossRef]

73. Kocheva, K.V.; Kartesva, T.; Landjeva, S.; Georgiev, G.I. Physiological response of wheat seedlings to mild and severe osmotic stress. Cereal Res. Commun. 2009, 37, 199-208. [CrossRef]

74. Mostofa, M.G.; Fujita, M. Salicylic acid alleviates copper toxicity in rice (Oryza sativa L.) seedlings by up-regulating antioxidative and glyoxalase systems. Ecotoxicology 2013, 22, 959-973. [CrossRef]

75. Daudi, A.; O’Brien, J.A. Detection of hydrogen peroxide by DAB staining in Arabidopsis leaves. Bio-Protocols 2012, 2, 1-4. [CrossRef]

76. Lichtenthaler, H.K. Chlorophylls and carotenoids pigments of photosynthetic membranes. Methods Enzymol. 1987, 148, 350-382. [CrossRef]

77. Sripakdee, T.; Sriwicha, A.; Jansam, N.; Mahachai, R.; Chanthai, S. Determination of total phenolics and ascorbic acid related to an antioxidant activity and thermal stability of the Mao fruit juice. Int. Food Res. J. 2015, 22, 618-624.

78. Mancinelli, A.L.; Rossi, F.; Moroni, A. Cryptochrome, phytochrome, and anthocyanin production. Plant Physiol. 1991, 96, 1079-1085. [CrossRef] [PubMed]

79. Moustakas, M.; Bayçu, G.; Sperdouli, I.; Eroğlu, H.; Eleftheriou, E.P. Arbuscular mycorrhizal symbiosis enhances photosynthesis in the medicinal herb Salvia fruticosa by improving photosystem II photochemistry. Plants 2020, 9, 962. [CrossRef] [PubMed]

80. Klughammer, C.; Schreiber, U. Analysis of light-induced absorbency changes in the near-infrared spectral region. 1. Characterization of various components in isolated chloroplasts. Z. Naturforsch. C 1991, 46, 233-244. [CrossRef]

81. Adamakis, I.-D.S.; Eleftheriou, E.P. Structural evidence of programmed cell death induction by tungsten in root tip cells of Pisum sativum. Plants 2019, 8, 62. [CrossRef] [PubMed]

82. Bosabalidis, A.M.; Kofidis, G. Comparative effects of drought stress on leaf anatomy of two olive cultivars. Plant Sci. 2002, 163, 375-379. [CrossRef] 